\title{
Autoimmune Polyglandular Syndrome Presenting with Jaundice and Thrombocytopenia
}

\author{
A.W. Norasyikin ${ }^{a} \quad$ M. Rozita ${ }^{\text {a }} \quad$ M.J. Mohd Johan ${ }^{b} \quad$ Z. Suehazlyn ${ }^{a}$ \\ a Pusat Perubatan Universiti Kebangsaan Malaysia (PPUKM), and ${ }^{\mathrm{b}}$ Hospital Angkatan Tentera Tuanku Mizan, \\ Kuala Lumpur, Malaysia
}

\section{Key Words}

Autoimmune thyroiditis · Pernicious anaemia .

Hypergastrinaemia · Autoimmune polyglandular syndrome

\begin{abstract}
Objective: To report an uncommon presentation of a rare case of autoimmune polyglandular syndrome type IIllb in an elderly woman. Clinical Presentation and Intervention: A 62-year-old woman presented with anaemic symptoms and jaundice. Blood tests showed macrocytic anaemia due to vitamin $B_{12}$ deficiency with Coombs negative haemolysis. A thyroid function test was consistent with hypothyroidism. Autoimmune antibody assays were positive for anti-parietal cell, anti-intrinsic factor and anti-thyroid peroxidase antibodies. A final diagnosis of autoimmune thyroiditis with pernicious anaemia, which constituted autoimmune polyglandular syndrome type IIIb, was made and the patient was treated with L-thyroxine, vitamin $B_{12}$ injection and a blood transfusion. She was discharged uneventfully after a week of hospitalization. Conclusion: This case showed that the presence of one autoimmune endocrine disease should prompt clinicians to look for other coexisting autoimmune diseases which may be asymptomatic despite positive autoantibodies.

(c) 2014 S. Karger AG, Basel
\end{abstract}

\section{Introduction}

Autoimmune polyglandular syndrome (APS) is a rare form of autoimmune disorder involving at least two glandular autoimmune-mediated diseases [1]. It is a combination of endocrine and non-endocrine autoimmune disorders [2]. In APS type III, there is an association between autoimmune thyroid disorders and other autoimmune diseases with an absence of Addison's disease and/or hypoparathyroidism [2]. The exact prevalence is unknown. APS type III can be further classified into 4 subcategories, i.e. a through $\mathrm{d}$. The presence of autoimmune thyroiditis is a prerequisite for all categories as shown in table $1[2$, 3]. Here we report a rare case of APS type IIIb in an elderly woman.

\section{Case Report}

A 62-year-old hypertensive woman presented with symptomatic anaemia for 3 weeks, associated with jaundice and lethargy. She had a history of gallstones and underwent a cholecystectomy at the age of 44. Apart from a history of colorectal carcinoma in her older sister, there was no history of any chronic illness in the family. Clinically, she was pale and jaundiced. She had coarse, dry hair and dry skin. There were no other abnormal findings.

Her haemoglobin was $5.3 \mathrm{~g} / \mathrm{dl}$, her mean cell volume was 108 $\mathrm{fl}$, her white cell count was $4.5 \times 10^{9} / \mathrm{l}$, and her platelet count was $77 \times 10^{9} / 1$. A full blood analysis showed leucoerythroblastic fea-

Dr. Norasykin A.Wahab

Department of Medicine

Pusat Perubatan Universiti Kebangsaan Malaysia (PPUKM)

Jalan Yaacob Latiff, Cheras, Kuala Lumpur 56000 (Malaysia)

E-Mail Naw8282kt@gmail.com 
Table 1. APS type III and subcategories

\begin{tabular}{|c|c|c|c|}
\hline \multicolumn{4}{|l|}{ Autoimmune thyroid disease } \\
\hline APS IIIa & APS IIIb & APS IIIC & APS IIId \\
\hline $\begin{array}{l}\text { Hashimoto's thyroiditis } \\
\text { Idiopathic myo-oedema } \\
\text { Asymptomatic thyroiditis }\end{array}$ & Endocrine exophthalmus & Endocrine exophthalmus & Grave’s disease \\
\hline $\begin{array}{l}\text { Endocrine diseases } \\
\text { Type } 1 \text { diabetes mellitus } \\
\text { Premature ovarian failure } \\
\text { Lymphocytic hypophysitis } \\
\text { Neurohypophysitis }\end{array}$ & $\begin{array}{l}\text { Gastrointestinal apparatus diseases } \\
\text { Atrophic gastritis } \\
\text { Pernicious anaemia } \\
\text { Coeliac disease } \\
\text { Chronic inflammatory bowel } \\
\text { disease } \\
\text { Autoimmune hepatitis } \\
\text { Primary biliary cirrhosis } \\
\text { Sclerosing cholangitis }\end{array}$ & $\begin{array}{l}\text { Skin/haemopoietic system/ } \\
\text { nervous system diseases } \\
\text { Vitiligo } \\
\text { Alopecia } \\
\text { Autoimmune } \\
\text { thrombocytopenia } \\
\text { Autoimmune haemolytic } \\
\text { anaemia } \\
\text { Anti-phospholipid syndrome } \\
\text { Myasthenia gravis } \\
\text { Stiff man syndrome } \\
\text { Multiple sclerosis }\end{array}$ & $\begin{array}{l}\text { Collagen diseases/ } \\
\text { vasculitis } \\
\text { Systemic lupus } \\
\text { erythematosus } \\
\text { Mixed connectivitis } \\
\text { Rheumatoid arthritis } \\
\text { Reactive arthritis } \\
\text { Scleroderma } \\
\text { Sjörgen's syndrome } \\
\text { Vasculitis }\end{array}$ \\
\hline
\end{tabular}

tures with polychromasia and ovalostomatocytosis. The total serum bilirubin level was elevated at $45 \mu \mathrm{mol} / \mathrm{l}$, with predominantly unconjugated forms and normal liver enzymes. Serum lactate dehydrogenase was elevated at 3,778 U/l but Coombs tests were negative. Her bone marrow aspirates and trephine biopsy showed severe megaloblastic anaemia without excess blast cells. Her thyroid profile revealed a free T4 level of $8.48 \mathrm{pmol} / 1$ (normal range 9.0$24)$ and the thyroid-stimulating hormone level was $83.96 \mathrm{IU} / \mathrm{ml}$ (normal range $0.3-5$ ). The serum vitamin $\mathrm{B}_{12}$ concentration was less than $44 \mathrm{pmol} / \mathrm{l}$ (normal range 145-637), with normal serum folate levels. The morning serum cortisol level was $445 \mathrm{nmol} / \mathrm{l}$ and after $250 \mu \mathrm{g}$ Synacthen the cortisol level increased to $798 \mathrm{nmol} / \mathrm{l}$ at $30 \mathrm{~min}$, representing an adequate response.

Her oesophagoduodenoscopy showed atrophic gastritis at the antrum. Both of her anti-gastric parietal cell and anti-intrinsic factor antibodies were positive. The anti-thyroid peroxidase level was more than $1,000 \mathrm{IU} / \mathrm{ml}$. Her fasting serum gastrin level was more than $1,000 \mathrm{pg} / \mathrm{ml}$ (normal range $<101$ ). Thus, she had both pernicious anaemia and Hashimoto's thyroiditis which led to the diagnosis of APS type IIIb.

She was treated with L-thyroxine, a vitamin $\mathrm{B}_{12}$ injection and a blood transfusion. Her white cell and platelet counts subsequently improved. She was discharged uneventfully after a week of hospitalization. During her follow-up, the L-thyroxine dose was adjusted to the optimal dose $(125 \mu \mathrm{g} /$ day $)$ and her thyroid profile normalized 3 months later.

\section{Discussion}

Our patient fulfilled the criteria for APS type IIIb, i.e. autoimmune thyroiditis due to Hashimoto's thyroiditis and pernicious anaemia. It occurs more frequently among middle-aged women $[4,5]$. In its early stages, destruction of the thyroid gland gives rise to transient hyperthyroidism referred to as Hashitoxicosis [5]. However, once the process is complete, it leads to hypothyroidism as was seen in our patient.

Pernicious anaemia is a sequela of autoimmune chronic atrophic gastritis that involves the fundic glands and is characterized by severe gland atrophy [6]. Almost $90 \%$ of patients have antibodies directed against the parietal cells [6]. As a result, pernicious anaemia leads to vitamin $B_{12}$ malabsorption and subsequently $B_{12}$ deficiency. This patient had both anti-gastric parietal cell and anti-intrinsic factor antibodies. She also had hypergastrinaemia which is a known complication of long-standing achlorrhydria due to a lack of acid secretion by the parietal cells of the stomach. The pronounced hypergastrinaemia $(>1,000$ $\mathrm{pg} / \mathrm{ml}$ ) likely leads to subsequent hyperplasia of gastric enterochromaffin-like cells which predisposes to gastric malignancy [7].

The treatment of APS depends on the organ involved and the accompanying hormonal deficiencies. This patient was treated with L-thyroxine replacement as well as intramuscular vitamin $B_{12}$ injection which she will require as lifelong therapy. However, it is important to highlight that autoimmune adrenalitis with accompanying adrenal insufficiency must be excluded before commencement of treatment with L-thyroxine.

APS is often preceded by an asymptomatic latency period of months or years following positive detection of 
antibodies [8]. It is characterized by the presence of circulating disease-associated antibodies which are useful markers for future organ failure [8]. Thus, regular and long-term glandular function monitoring seems necessary. This is important because early recognition and replacement therapy can be life saving, particularly when the glandular failure involves the adrenal glands. Although the gland involvement in APS type III is usually limited to 2 or 3 glands, extensive involvement of up to 7 autoimmune diseases with extensive circulating antibodies including anti-glutamic acid decarboxylase antibodies and islet cell antibodies has been reported [9].

Hence, long-term follow-up and screening for other possible glandular involvements is necessary for our patient. Surveillance monitoring for gastric carcinoid tumours, which have been reported in $3-5 \%$ of patients with hyperplasia of gastric enterochromaffin-like cells, should also be performed [7]. Furthermore, pernicious anaemia is also associated with an increased risk of gastric cancer [10].

\section{Conclusion}

This case showed that the presence of one autoimmune endocrine disease should prompt clinicians to look for other coexisting autoimmune diseases which may be asymptomatic despite positive autoantibodies. This is especially important in patients with autoimmune hypothyroidism and undetected adrenal insufficiency because corticosteroid replacement before thyroxine therapy is mandatory to avoid an adrenal crisis.

\section{References}

1 Kahaly GJ: Polyglandular autoimmune syndromes. Eur J Endocrinol 2009;161:11-20.

$>2$ Betterle C, Zanchetta R: Update on autoimmune polyendocrine syndromes (APS). Acta Biomed 2003;74:9-33.

-3 Arya RK, Gupta DK, Chaudhary SC, et al: A rare case of autoimmune polyglandular syndrome type IIIc. Indian J Endocrinol Metab 2012;16:480.

4 Jain J, Banait S, Jajoo UN, et al: Polyglandular autoimmune syndrome: we should entertain this possibility more than often. Thyroid Res Pract 2012;9:93-95.
5 Fatourechi V, McConahey WM, Woolner LB, et al: Hyperthyroidism associated with histologic Hashimoto's thyroiditis. Mayo Clin Proc 1971;46:682-689.

6 Davidson RJ, Atrah HI, Sewell HF, et al: Longitudinal study of circulating gastric antibodies in pernicious anaemia. J Clin Pathol 1989; 42:1092-1095.

7 Harvey RF, Bradshaw MJ, Davidson CM, et al: Multifocal gastric carcinoid tumours, achlorhydria, and hypergastrinaemia. Lancet 1985; 1:951-954.
8 Dittmar M, Kahaly GJ: Polyglandular autoimmune syndromes: immunogenetics and longterm follow-up. J Clin Endocrinol Metab 2003;88:2983-2992.

-9 Shimomura H, Nakase Y, Furuta H, et al: A rare case of autoimmune polyglandular syndrome type 3. Diabetes Res Clin Pract 2003; 61:103-108.

10 Ahn MJ, Han D, Park YJ, et al: A case of type IIa early gastric cancer developed in pernicious anemia. J Korean Med Sci 1998;13:8184. 